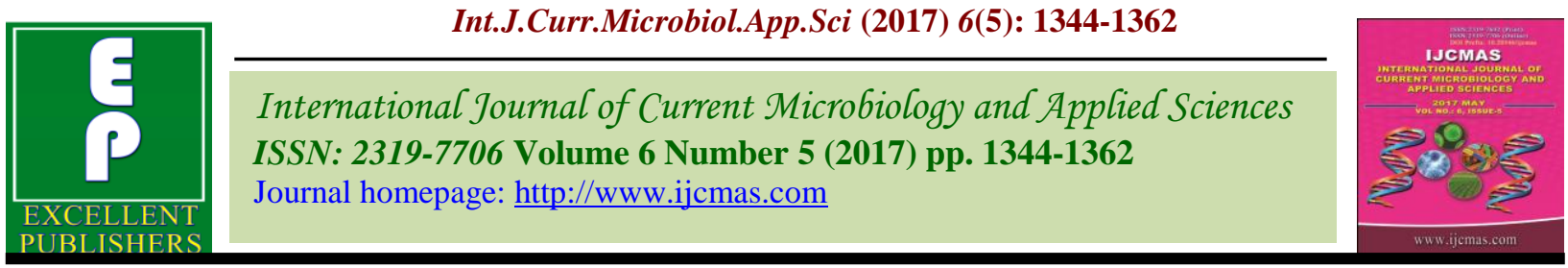

Original Research Article

https://doi.org/10.20546/ijcmas.2017.605.146

\title{
Treatment of Leachate from Urban Waste Using Coagulation-Flocculation and Adsorption
}

\author{
H. Zouaghi ${ }^{1^{*}}$, M. Ruiti ${ }^{2}$ and B. Ben Thayer ${ }^{3}$ \\ ${ }^{1}$ National Engineering School of Monastir, Avenue Ibn El Jazzar, 5019, Monastir, Tunisia \\ ${ }^{2}$ National Agronomy Institute of Tunis, 43 Avenue Charles Nicolle, 1082, Tunis, Tunisia \\ ${ }^{3}$ High Institute of Rural Engineering and Equipment Medjez El Bab, Laboratory of chemistry \\ and water quality, 9070, Medjez El Bab, Beja, Tunisia \\ *Corresponding author
}

A B S T R A C T

Keywords

Leachate,

Coagulation-

Flocculation,

Adsorption,

Treatment.

Article Info

Accepted:

12 April 2017

Available Online:

10 May 2017

The present work deals with the leachate treatment using the following processes: coagulation-flocculation by alumina sulfate followed by anionic polyelectrolyte, on one hand. This treatment is preceded by a pretreatment using $\mathrm{NaOH}$ and $\mathrm{KOH}$. On the other hand, adsorption by bark Alep pine powder and fibers of date palm leaves is used. Monitoring of physicochemical parameters of that leachate gave a $\mathrm{pH}$ of 8,46 ; an electrical conductivity of $18,24 \mathrm{mS} / \mathrm{cm}$, an orthophosphate concentration of $0,35 \mathrm{mg} / 1$, an oxidability of $125 \mathrm{mg} \mathrm{O}_{2} / \mathrm{l}$ and a turbidity of $252 \mathrm{FAU}$. Pretreatment with precipitation was considered. For treatment by coagulation - flocculation and for the precipitation, Leachate treatment preceded by pretreatment gives better results with optimal doses. Note that the best pretreatment is by soda which gives an optimum turbidity of 54FAU with minimum doses of alumina sulfate. Then, using adsorption for leachate treatment requires the least investment cost. Adsorption with $2 \mathrm{~g}$ of Alep pine bark/100ml of leachate gave the best results of turbidity.

\section{Introduction}

Faced with population growth, improving the life quality and the high density of urban areas, new forms of water pollution are generated. Indeed, burial and storage of solid waste should not only allow the effective management of waste but also the treatment and recovery after drainage of effluents that are both biogas and leachate.

Effectively, from the deposition phase, waste is subjected to degradation processes linked to complex biological and physicochemical reactions. Water infiltrates and produces leachate and biogas laden with organic and inorganic substances, which cause pollution mainly organic and metallic in relation to the natural biodegradation of confined waste and with their anthropogenic components which release many toxic substances in the environment, including the atmosphere, groundwater, and streams.

As regulation is increasingly strict, in rejection terms and due to their polluting load, the leachates must undergo a purification treatment before being discharged to the natural environment. In this regard, many studies have focused on leachate treatment. 
Several leachate treatment systems were used. Some treatments are physicochemical and others are biological. The choice of treatment depends mainly on the type of leachate that may be young, medium or old depending on their composition. The choice may also depend on the type of treatment you want to choose.

Papadopoulos et al., (1998) worked on leachate treatment. With $1500 \mathrm{mg} / \mathrm{l}$ of lime and $1000 \mathrm{mg} / \mathrm{l}$ of aluminum sulfate (Al2 (SO4)3), the decrease in COD doesn't exceed $42 \%$ on stabilized leachates having a COD of between 6000 and $8200 \mathrm{mgO} 2 / \mathrm{l}$.

Precipitation is also used at the end of the leachate treatment line. Baig et al., (1999) observed the elimination of $27 \%$ of the residual COD by adding $1 \mathrm{~g} / \mathrm{l}$ of lime to an effluent treated by precipitation with ferric chloride and then to a biological reactor. This value can be slightly improved by increasing the amount of lime added but the volume of sludge quickly becomes large.

Many researches are focused on leachate treatment by coagulation-flocculation with ferric chloride. It's a simple technique to apply. However, it generates fine sludge and difficult to separate. Edeline (1993) find that COD removal efficiencies range is from 25 to $75 \%$. The treated leachate must be neutralized before discharge, by adding small quantities of alkali, the water losing all buffering capacity by this process.

Edeline (1993) used adsorption for leachate treatment. The COD fixed on an activated carbon are on the order of $200 \mathrm{mg} \mathrm{COD} / \mathrm{g}$ of activated carbon. The $\mathrm{pH}$ at which adsorption is carried out is of great importance. At a $\mathrm{pH}$ close to neutrality, the adsorption gives good results. In a very acid medium, precipitation is observed, or an apparent increase in adsorption relative to the adsorption in neutral medium. In a basic medium, this process gives unsatisfactory results, the adsorbable compounds being predominantly in ionized form.

This work is about leachate treatment. Two processes are used. Firstly, the leachates are chemically treated, by the coagulationflocculation method using alumina sulfate $\mathrm{Al} 2$ (SO4)3 as a coagulant and the anionic polyelectrolyte as a flocculant. The treatment with coagulation-flocculation will be preceded by chemical precipitation by caustic soda $\mathrm{NAOH}$ and potassium hydroxide $\mathrm{KOH}$. In a second step, biological leachate treatment is used. For the adsorbing agents, it is the date palm leaves and the bark of Alep pine in powders. Activated carbon is used as a reference adsorbent.

\section{List of symbols}

$\begin{array}{ll}\mathrm{pH} & \text { hydrogen potential } \\ \mathrm{m} 0 & \text { filter paper mass before } \\ \text { measurements (mg) } \\ \mathrm{m} 1 & \text { filter paper mass } \\ (\mathrm{mg}) & \\ \mathrm{NaOH} & \text { hydrox filtration } \\ \mathrm{KOH} & \text { hydroxide of sodium } \\ \mathrm{P} 1 \text { and } \mathrm{P} 0 & \text { masses in beaker before and after } \\ \text { evaporation } & (\mathrm{mg}) \\ \mathrm{SM} & \text { suspended matter } \\ \mathrm{V} & \text { sample volume }(\mathrm{ml}) .\end{array}$

\section{Materials and Methods}

\section{Leachate characteristics}

Leachates are collected from the controlled landfill of Medjez El Bab, a small town of 20 thousand inhabitants, located in the northwest of Tunisia. Its characteristics are presented in Table 1. In relation to the Tunisian standard of rejection in the maritime public domain, this leachate isn't conformal. To be rejected, $\mathrm{pH}$ must be between 6,5 and 8,5. The 
Suspended matter shall not exceed $0,03 \mathrm{~g} / \mathrm{l}$ and the orthophosphates concentration of $0,001 \mathrm{mg} / \mathrm{l}$.

As regards the Tunisian standard for discharge in public canalization, $\mathrm{pH}$ has to be between 6,5 and 9. The Suspended matter hasn't overtaken $0,4 \mathrm{~g} / 1$ and the orthophosphates concentration has to be less than $0,01 \mathrm{mg} / \mathrm{l}$. So, Leachate needs to be treated.

\section{Measurement protocol}

The sample analyzes were carried out in the chemistry and water quality laboratory. The aim is to determine leachate physicochemical characteristics before and during treatment. It consists of determining $\mathrm{pH}$, electrical conductivity (CE), Suspended matter (SM), the dry residue (RS), Oxidability, determination of orthophosphates and turbidity.

The $\mathrm{pH}$-meter used is Mettler Toledo MP 220. It is calibrated using two buffer solutions (pH4 and $\mathrm{pH} 7$ ).

The apparatus used for measuring the electrical conductivity is the conductivity meter WTW LF 521. It is previously calibrated and the analysis is carried out in a beaker containing $50 \mathrm{ml}$ of water. This instrument measures conductivity in $\mathrm{mS} / \mathrm{cm}$ or $\mu \mathrm{S} / \mathrm{cm}$. Suspended matter measurement follows this method:

Rinse a filter paper with distilled water to remove the starch and place it in the stove at $105^{\circ} \mathrm{C}$ until dry.

Insert the filter paper into the desiccators to cool and avoid moisture for $15 \mathrm{~min}$.

Weigh the mass $\mathrm{m} 0$ of the filter paper.

After rinsing with distilled water, place it on the filtration unit and add a definite volume (V) of the sample.

Place the filter in the stove at $105^{\circ} \mathrm{C}$ until constant weight.

Weigh the filter paper and record its mass $\mathrm{m} 1$. The SM is given in this formula:

The determination of the dry residue (DR) follows this procedure:

In a previously weighed beaker, introduce a water volume $\mathrm{V}$.

Evaporate gradually on a preheated plate. When the remaining amount becomes very low, transfer the beaker to the oven at $105^{\circ} \mathrm{C}$, wait for complete water evaporation.

Remove the beaker; allow it cooling in the desiccator and weigh.

The DR takes this form:

The oxidability is determined to evaluate the polluting load of waste water. The measurement of oxidability using potassium permanganate consists of oxidizing organic materials oxidable by $\mathrm{KMnO} 4$ at warm.

It consists of introducing successively into 2 erlenmeyers the following quantities:

Erlenmeyer 1 of $250 \mathrm{ml}$ :

$100 \mathrm{ml}$ of water;

$10 \mathrm{ml}$ of saturated $\mathrm{NaHCO} 3$ solution; $10 \mathrm{ml}$ of $\mathrm{KMnO} 4$ solution, $\mathrm{N} / 80$.

Erlenmeyer 2 of $500 \mathrm{ml}$ :

$200 \mathrm{ml}$ of water; $20 \mathrm{ml}$ of saturated $\mathrm{NaHCO} 3$ solution; $20 \mathrm{ml}$ of $\mathrm{KMnO} 4$ solution, N/80.

Bring the 2 containers to ebullition; boil 10 minutes from the moment when the bubbles come to puncture the liquid surface.

Allow to cool during 30min in air stream;

Add $10 \mathrm{ml}$ of $\mathrm{H} 2 \mathrm{SO} 4(50 \%)$ in erlenmeyer 1 and $20 \mathrm{ml}$ in erlenmeyer 2;

Add $10 \mathrm{ml}$ of Mohr salt to each Erlenmeyer until obtaining a total discolouration (shake if necessary); 
Let cool again;

Return to the weak but persistent pink tint by introducing the solution of potassium permanganate $\mathrm{N} / 80$ with a graduated burette.

The difference $\mathrm{V}$ between $\mathrm{V} 2$ and $\mathrm{V} 1$ of $\mathrm{KMnO} 4$ (N/80) measured during two titrations, represents the amount of $\mathrm{KMnO} 4$ used to oxidize the organic matter in $100 \mathrm{ml}$ of water to be analyzed. By convention, it also corresponds to the number of milligrams of oxygen consumed, per liter of water, for this oxidation.

To determine the phosphorus concentration, the orthophosphate assay method is used. However, it's necessary to establish the calibration curve which gives the phosphorus concentration as function of the absorbance. The aim is to determine the different forms of phosphates contained in leachate. It can be classified as orthophosphates which indicate the presence of fertilizers or polyphosphates proof of detergents or other organic compounds.

The procedure is as follows:

Introduce $20 \mathrm{ml}$ of water into a $25 \mathrm{ml}$ flask;

Add 1ml of ascorbic acid and shake;

Add $4 \mathrm{ml}$ of combined reagent (which is obtained by mixing $50 \mathrm{ml}$ of $5 \mathrm{~N}, \mathrm{H} 2 \mathrm{SO} 4,5 \mathrm{ml}$ of tartrate and $15 \mathrm{ml}$ of molybdate) and stirring;

Wait 30min until the appearance of a blue color;

Perform a spectrophotometer reading at a wavelength of $880 \mathrm{~nm}$;

Refer to the calibration curve to evaluate reading in orthophosphates. The turbidity measurement of leachate comes within the framework of the development of a possible clarification treatment, after treatment to check for proper operation.

Turbidity is measured with a $\mathrm{HACH}$ DR/4000U spectrophotometer. The unit of measurement of the turbidity used is the FAU (Formazine Attenuation Unit) at a wavelength $\lambda=860 \mathrm{~nm}$.

\section{Leachate treatment techniques}

Depending on the leachates physicochemical characteristics, it is necessary to treat these liquid effluents. Two treatment methods are used. The first is a physicochemical method and the second is biological. The aim is to compare each treatment process and determine the appropriate one for this liquid effluent before choosing its recovery way.

\section{Physicochemical treatment Coagulation - flocculation}

The coagulation - flocculation of leachate is carried out with alumina sulfate as the most available and least expensive coagulant for optimum results. Its characteristics are presented in table 2. There are, in fact, other coagulants such as iron chloride. However, it is expensive and requires a lengthy administrative procedure in order to be used.

The flocculant used is the anionic polyelectrolyte. After adding different quantities of the coagulant and/or flocculant in a $100 \mathrm{ml}$ solution of leachate placed in 4 plastic beakers, a fast stirred 200rpm for 2 min is followed by slow stirring for $10 \mathrm{~min}$ at a velocity of $20 \mathrm{rpm}$ using a flocculator. The method used is the Jar test technique.

The 4 beakers are then put to rest for decanting. Subsequently, the various parameters for monitoring the supernatant solution are determined. 
During the coagulation process, three tests were performed. The aim consists of determining the volume corresponding to the optimum turbidity. After fixing the volume of the coagulant, we vary the dose of flocculant. This operation is carried out in two tests.

\section{Leachate pre-treatment}

In order to minimize coagulant and flocculant doses, corresponding to the minimum turbidity, the leachate is pretreated. This method objective is to improve the quality of the leachate before coagulation - flocculation treatment.

The principle consists in adding defined doses of a chosen base and measuring the $\mathrm{pH}$ per dose introduced. The $\mathrm{pH}$ is set at 8,5; 9; 9,5; 10 and 10,5 per liter of leachate. Once the $\mathrm{pH}$ is set, the solution is standing until decanting and coagulant - flocculation tests began.

The pretreatment used is chemical precipitation by various bases, caustic soda, and potassium hydroxide. The characteristics of these products are presented in Table 3 .

\section{Biological treatment: Adsorption}

The leachate treatment by adsorption is the least costly and most suitable method of product availability. But, it remains the choice of the best adsorbent.

In a first step, the stirring time was set at $2 \mathrm{~h}$ and the stirring speed was set at 300rpm.

In 5 erlenmeyers, $100 \mathrm{ml}$ of leachate and increasing quantities of adsorbent $(2,4,6,8$ and $10 \mathrm{~g}$ ) were introduced. Agitation is carried out for $2 \mathrm{~h}$ using a magnetic bar and stirrer of AGIMATIC-S type. Samples are allowed to stand for $1 / 2 \mathrm{~h}$. Filtration of each sample is then carried out using filter paper previously washed with distilled water.
Adsorbents used are date palm leaves and Aleppo pine bark. The activated charcoal is used as a reference.

\section{Adsorbents preparation}

The palm leaves and the pine bark of Alep are cut, well washed with tap and distilled water in order to remove impurities. They are then dried in the stove for $2 \mathrm{~h}$ at $105^{\circ} \mathrm{C}$. The final step consists of crushing. The adsorbent takes the form presented in figure 1. For every adsorbent quantity, stirring time varies (10, 20, 30, 60 and 120min). The tracking parameters are determined.

\section{Results and Discussion}

The leachates are treated using two methods. On one hand, the coagulation-flocculation is used as the best treatment for leachate having a high turbidity. On the other hand, a biological treatment is used. It's adsorption. The results are then compared.

\section{Leachate treatment by coagulation- flocculation}

This part is devoted to the leachate treatment using coagulation-flocculation. As previously mentioned, the coagulant used is alumina sulfate. For the flocculant, it is the anionic polyelectrolyte. Given their high initial turbidity of 252FAU, a pretreatment with precipitation is envisaged for the leachate. Two bases are used for precipitation. These are the soda $\mathrm{NaOH}$ and the potassium hydroxide $\mathrm{KOH}$. Results are then compared. Coagulation-flocculation can be used successfully in the treatment of old leachates (Silva et al., 2004). It is widely used as a pretreatment (Amokrane et al., 1997) before reverse osmosis or before biological processes or as the last stage of treatment in order to remove bio-recalcitrant organic matter (Trabelsi, 2012). 
Aluminum sulfate, ferrous sulfate, ferric chloride and ferric chlorosulfite have been commonly used as coagulants by Ehrig et al., (1984). However, Zouboulis et al., (2004) showed that bio-flocculants are more efficient than inorganic flocculants.

This process has disadvantages, such as the production of a large quantity of sludge and the decrease in the concentration of aluminum or iron in the liquid phase.

Figure 2 is about turbidity variation as function of the dose of alumina sulfate for different pHs. It's deceasing at first. So, the addition of coagulant (alumina sulfate) has a positive influence on the turbidity which continues its decrease. The turbidity is the minimum for a determined coagulant quantity which depends on $\mathrm{pH}$ initial solution and the type of precipitant. Then, comes an increasing part, during which the addition of the dose of alumina sulfate progressively increases the turbidity. This indicates that from a certain dose, the coagulant has a bad influence on turbidity.

It is observed that the minimum of turbidity corresponds to the high initial $\mathrm{pH}$. This is shown even for $\mathrm{NaOH}$ precipitation than for $\mathrm{KOH}$.

Note that for crude leachate the minimum turbidity is 63FAU, while for leachates precipitated with soda at $\mathrm{pH}=10,5$; the minimum of turbidity is about 55FAU.

On the other hand, the dose of alumina sulfate decreases to reach a minimum of turbidity for crude leachate comparing with the precipitated leachate using soda, at $\mathrm{pH}=8,5$ to 10,5 . For crude leachate, the dose of alumina sulfate is $0,95 \mathrm{~g} / \mathrm{l}$ which correspond to the minimum of turbidity. This dose decreases with precipitation with soda at $\mathrm{pH}=8,5$ to $0,85 \mathrm{~g} / \mathrm{l}$ up to $0,2 \mathrm{~g} / \mathrm{l}$ for precipitation at
$\mathrm{pH}=10,5$. This is explained by the pretreatment of the leachate by chemical precipitation, which, despite the increase in $\mathrm{pH}$, reduces the turbidity.

By comparing the turbidity curves for crude leachate and those treated without precipitation using $\mathrm{KOH}$, it's seen that chemical precipitation plays an important role in decreasing turbidity. A decrease in turbidity from 90 to 60FAU for coagulant doses between 0,2 and $0,95 \mathrm{~g} / 1$ is noted. However, for pretreated leachate at $\mathrm{pH}=$ 10,5 ; the decrease is 64 to 57FAU for doses between 0,2 and $0,5 \mathrm{~g} / 1$ of alumina sulphate. This also indicates that the higher the dose used for precipitation, the lower the dose of alumina sulfate used to achieve minimum turbidity.

Researchers have used ferric chloride $\mathrm{FeCl}_{3}$ as a more effective coagulant than aluminum sulfate for the treatment of leachate (Thornton, 1973) and (Slater et al., 1983).

The test Jar tests were carried out under stirring conditions of $160 \mathrm{rpm}$ for $5 \mathrm{~min}$ for coagulation and 40rpm for $20 \mathrm{~min}$ to promote flocculation and then $2 \mathrm{~h}$ of sedimentation.

The results obtained gave that the turbidity curve as a function of the coagulant dose does not have a conventional appearance. Certainly, a small dose of $\mathrm{FeCl}_{3}$ causes a drop in turbidity. The maximum yield obtained was $99,16 \%$ for a dose of $1,4 \mathrm{~g} \mathrm{FeCl}_{3} / 1$. Ferric chloride would be a more effective coagulant than aluminum sulfate to reduce COD. Thus, for a dose of $1 \mathrm{~g} / \mathrm{l}$ ferric chloride, the reduction of COD on a leachate from a methanogenic phase discharge is $53 \%$ compared to only $33 \%$ of the same mass of aluminum sulfate (Welanden et al., 1998).

The variation of electrical conductivity for different coagulant doses, presented in figure 
3 , indicates the salinity rate in the leachate solution.

A slight decrease in electrical conductivity is observed when the dose of alumina sulfate increases. So, salinity decreases as the dose of alumina sulfate increases. This can be observed for all cases. For a coagulation of leachate without precipitation, a reduction in the electrical conductivity of 16,5 to $11,15 \mathrm{mS} / \mathrm{cm}$ for doses of 0,2 to $2 \mathrm{~g} / \mathrm{l}$ of alumina sulphate, whereas for precipitated leachate using soda at $\mathrm{pH}=10,5$ and then treated by coagulation, electrical conductivity decreased from 11,74 to $9,5 \mathrm{mS} / \mathrm{cm}$ for doses between 0,05 and $0,8 \mathrm{mS} / \mathrm{cm}$.

It's found that the lower the precipitation $(\mathrm{pH})$, the lower is salinity. For $\mathrm{KOH}$ precipitation at $\mathrm{pH}=8,5$; a decrease of nearly 15,83 to $7,22 \mathrm{mS} / \mathrm{cm}$ whereas for a precipitation at $\mathrm{pH}=10,5$; it's from 14,56 to $10,05 \mathrm{mS} / \mathrm{cm}$ for alumina sulphate doses between 0,2 and $0,9 \mathrm{~g} / \mathrm{l}$ of.

To compare the three solutions, the leachate pretreated using soda has the lower electrical conductivity whatever is the $\mathrm{pH}$. So if the aim is to increase leachate salinity, it would better to use precipitation with soda.

The variation of the orthophosphates concentration in leachate is presented in figure 4. Figure 4 shows that the $\mathrm{PO}_{4}^{3-}$ concentration decreases with the increase of coagulant dose. It also shows that the greater the precipitation, the smaller the dose at which phosphorus is eliminated. It should be noted that for raw leachate and for a $0,2 \mathrm{~g} / \mathrm{l}$ of $\mathrm{Al}_{2}\left(\mathrm{SO}_{4}\right)_{3}$ dose, the phosphorous concentration is about $0,15 \mathrm{mg} / \mathrm{l}$ in comparison with leachate precipitated using soda at $\mathrm{pH}=9$ with the same coagulant dose. The concentration of orthophosphates is $0,09 \mathrm{mg} / \mathrm{l}$. For a precipitation at $\mathrm{pH}=10,5$; the concentration is about $0,07 \mathrm{mg} / \mathrm{l}$.
The concentration of the orthophosphates is zero by the addition of anionic polyelectrolyte even at low doses. Without pretreatment, phosphorous disappears at a coagulant dose of $0,8 \mathrm{~g} / \mathrm{l}$, en comparison with soda precipitation where phosphorous is eliminated at coagulant dose of $0,4 \mathrm{~g} / \mathrm{l}$.

Oxidability variation of treated leachate as function of coagulant dose is presented in figure 5. It's seen that it decreases with the increase of coagulant dose. This is observed for all cases. This decrease indicates that alumina sulfate removes some of the organic matter.

Note that the greater the precipitation, the smaller the oxidability. For example, for precipitation using soda at $\mathrm{pH}=8,5$; and for an alumina sulfate dose of $0,2 \mathrm{~g} / \mathrm{l}$, oxidability is about 26,5mg $\mathrm{O}_{2} / 1 \quad$ compared with precipitation at $\mathrm{pH}=10,5$ where oxidability is $14 \mathrm{mg} \mathrm{O}_{2} / \mathrm{l}$ for the same coagulant dose.

For $\mathrm{KOH}$ precipitation, the decrease is from 25 to $12 \mathrm{mg} \mathrm{O}_{2} / 1$ at $\mathrm{pH}=8,5$ compared with precipitation at $\mathrm{pH}=10,5$ where oxidability decreases from 14 to $6 \mathrm{mg} \mathrm{O}_{2} / \mathrm{l}$ for a coagulant dose between 0,2 and $0,8 \mathrm{~g} / \mathrm{l}$.

Fixing the dose of alumina sulfate which corresponds to the minimum turbidity, the dose of flocculant varies. It should be remembered that the flocculant used in this experiment is anionic polyelectrolyte. The results are presented in figure 6.

Figure 6 shows the variation in turbidity versus the dose of anionic polyelectrolyte with soda precipitated leachate followed by coagulation. It indicates that after fixing the dose of alumina sulfate, the addition of anionic polyelectrolyte allows an improvement (decrease) in the turbidity of the leachates. For example, the addition of $0,95 \mathrm{~g} / \mathrm{l}$ allowed turbidity of 63FAU and by the 
addition of $0,003 \mathrm{~g} / \mathrm{l}$ of flocculant, the turbidity is 57FAU.

Figure 6 is also characterized by a first descending part which indicates that the addition of flocculant allows the turbidity to be reduced. Then there is an upward part, during which the anionic polyelectrolyte plays the opposite role since, despite the addition of the latter, the turbidity continues to increase.

Table.1 Leachate characteristics

\begin{tabular}{|l|c|c|}
\hline \multicolumn{1}{|c|}{ Designation } & Unit & Value \\
\hline $\mathrm{pH}$ & - & 8,46 \\
\hline electrical conductivity & $\mathrm{mS} / \mathrm{cm}$ & 18,24 \\
\hline Salinity & $\mathrm{g} / \mathrm{l}$ & 12,55 \\
\hline Dry residue & $\mathrm{g} / \mathrm{l}$ & 21,88 \\
\hline Suspended matter & $\mathrm{g} / \mathrm{l}$ & 12,3 \\
\hline Orthophosphates concentration & $\mathrm{mg} / \mathrm{l}$ & 0,35 \\
\hline Oxidability & $\mathrm{mg} \mathrm{O} / /$ & 125 \\
\hline Color & - & Dark brown \\
\hline Smell & - & bad \\
\hline Turbidity & FAU & 252 \\
\hline
\end{tabular}

Table.2 Coagulant and flocculant characteristics

\begin{tabular}{|c|c|c|c|}
\hline Designation & Purpose & Used form & Mother solution \\
\hline $\begin{array}{c}\text { Alumina sulphate } \\
\mathrm{Al}_{2}\left(\mathrm{SO}_{4}\right)_{3}\end{array}$ & Coagulant & Powder & $10 \mathrm{~g} / 1$ \\
\hline anionic polyelectrolyte & Flocculant & Powder & $1 \mathrm{~g} / \mathrm{l}$ \\
\hline
\end{tabular}

Table.3 Characteristics of bases used for chemical precipitation of leachates

\begin{tabular}{|c|c|c|c|c|}
\hline Designation & Molar mass & Used form & Mother solution & Notes \\
\hline Caustic soda $\mathrm{NaOH}$ & 40 & Solid in flakes & $0,1 \mathrm{~N}$ & $\begin{array}{c}\text { Dangerous } \\
\text { corrosive }\end{array}$ \\
\hline Potassium hydroxide $\mathrm{KOH}$ & 56 & Crystals & $5 \mathrm{~N}$ & - \\
\hline
\end{tabular}

Fig.1 Adsorbent form before and after preparation

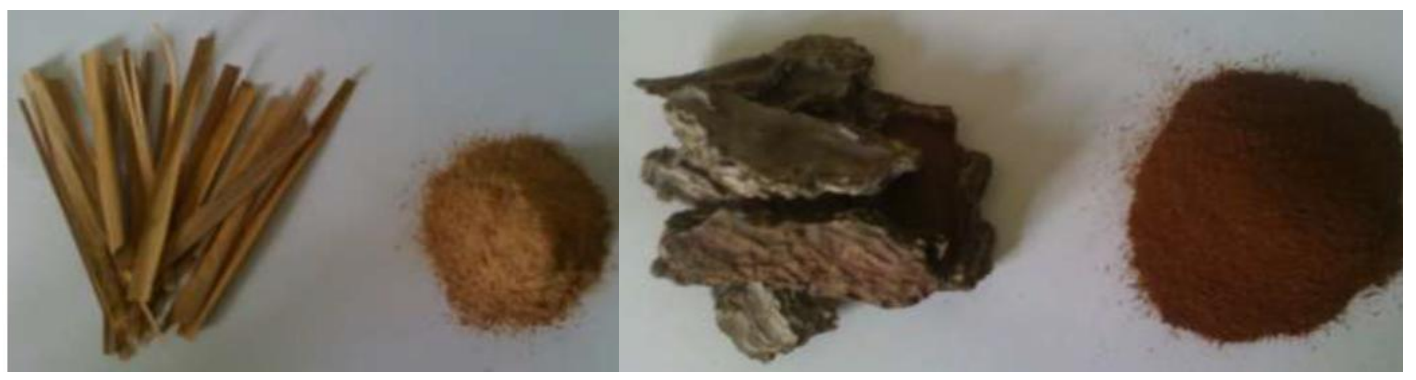


Table.4 Summary table of leachate characteristics after soda precipitate and coagulation flocculation

\begin{tabular}{|c|c|c|c|c|c|c|}
\hline Precipitation $\mathrm{pH}$ & $\begin{array}{c}\text { Without } \\
\text { precipitation }\end{array}$ & $\mathrm{pH}=8,5$ & $\mathrm{pH}=9$ & $\mathrm{pH}=9,5$ & $\mathrm{pH}=10$ & $\mathrm{pH}=10,5$ \\
\hline Coagulant dose $(\mathrm{g} / \mathrm{l})$ & 0,95 & 0,85 & 0,50 & 0,50 & 0,20 & 0,20 \\
\hline Flocculant dose $(\mathrm{mg} / \mathrm{l})$ & 3 & 3 & 3,50 & 3 & 3 & 3 \\
\hline $\mathrm{pH}$ & 6,64 & 7,05 & 6,22 & 6,55 & 7,64 & 6,63 \\
\hline $\begin{array}{c}\text { Electrical conductivity } \\
(\mathrm{mS} / \mathrm{cm})\end{array}$ & 10,21 & 12,78 & 9,75 & 11,79 & 14,21 & 12,28 \\
\hline Salinity $(\mathrm{g} / \mathrm{l})$ & 7,02 & 8,79 & 6,71 & 8,11 & 9,78 & 8,45 \\
\hline $\mathrm{PO}_{4}^{3-}$ concentration \\
$(\mathrm{mg} / \mathrm{l})$
\end{tabular}

Table.5 Summary table of leachate characteristics after $\mathrm{KOH}$ precipitate and coagulation flocculation

\begin{tabular}{|c|c|c|c|c|c|c|}
\hline Precipitation $\mathrm{pH}$ & $\begin{array}{c}\text { Without } \\
\text { precipitation }\end{array}$ & $\mathrm{pH}=8,5$ & $\mathrm{pH}=9$ & $\mathrm{pH}=9,5$ & $\mathrm{pH}=10$ & $\mathrm{pH}=10,5$ \\
\hline Coagulant dose $(\mathrm{g} / \mathrm{l})$ & 0,95 & 0,80 & 0,60 & 0,60 & 0,50 & 0,50 \\
\hline Flocculant dose $(\mathrm{mg} / \mathrm{l})$ & 3 & 7,50 & 6 & 6 & 6 & 5,50 \\
\hline $\mathrm{pH}$ & 6,64 & 6,03 & 7,31 & 6,31 & 7,39 & 7,49 \\
\hline Electrical conductivity $\mathrm{mS} / \mathrm{cm})$ & 10,21 & 11,62 & 12,86 & 12,41 & 13,54 & 10,81 \\
\hline Salinity $(\mathrm{g} / \mathrm{l})$ & 7,02 & 7,99 & 8,85 & 8,54 & 9,32 & 7,44 \\
\hline $\mathrm{PO}_{4}^{3-}$ concentration $(\mathrm{mg} / \mathrm{l})$ & 0 & 0 & 0 & 0 & 0 & 0 \\
\hline Oxidability $\left(\mathrm{mg} \mathrm{O}_{2} / \mathrm{l}\right)$ & 11,50 & 16,50 & 15,50 & 14 & 10 & 9 \\
\hline Turbidity $(\mathrm{FAU})$ & 57 & 63 & 58 & 56 & 56 & 56 \\
\hline
\end{tabular}


Fig.2 Turbidity variation as function of coagulant dose
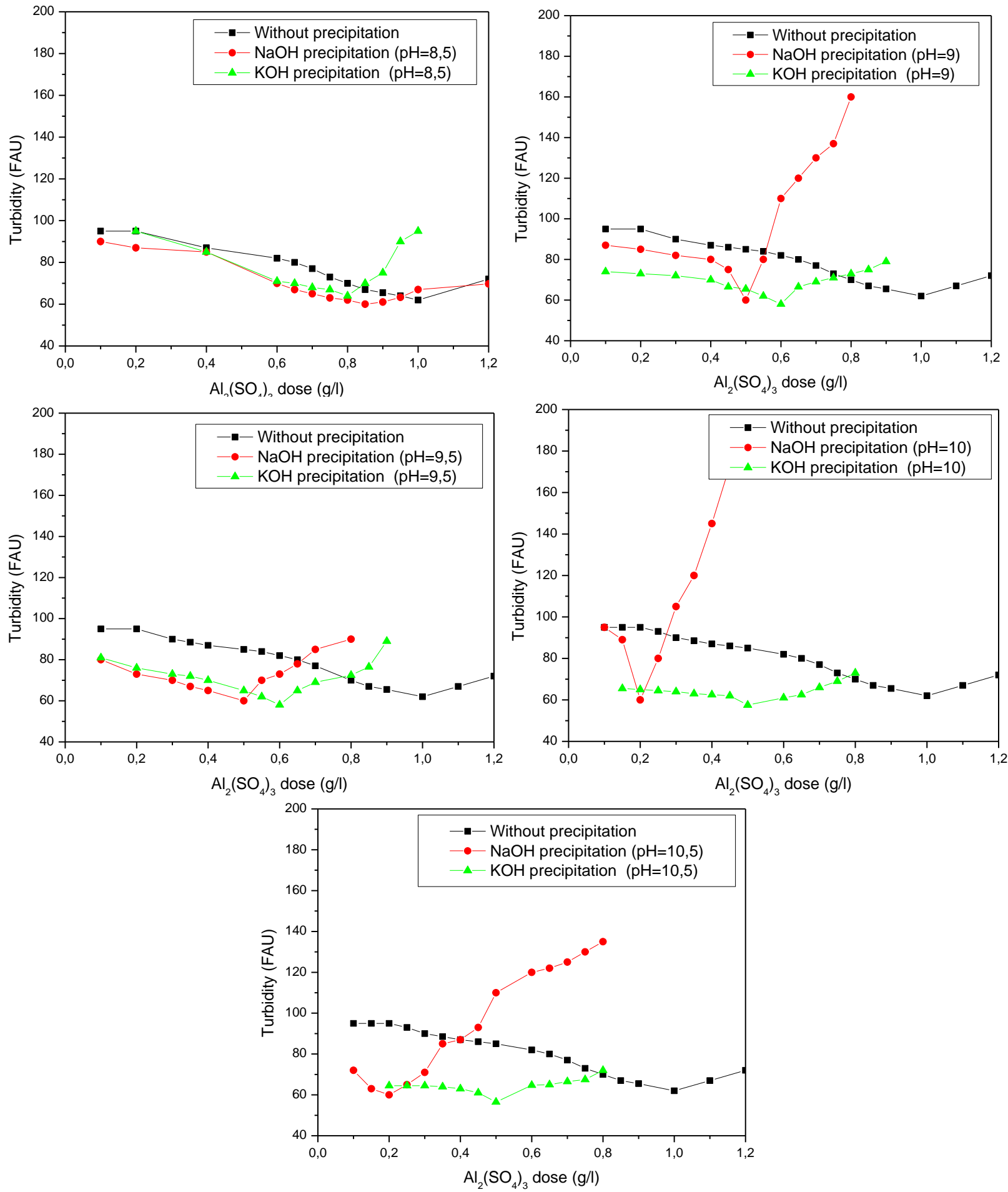
Fig.3 Electrical conductivity variation as function of coagulant dose
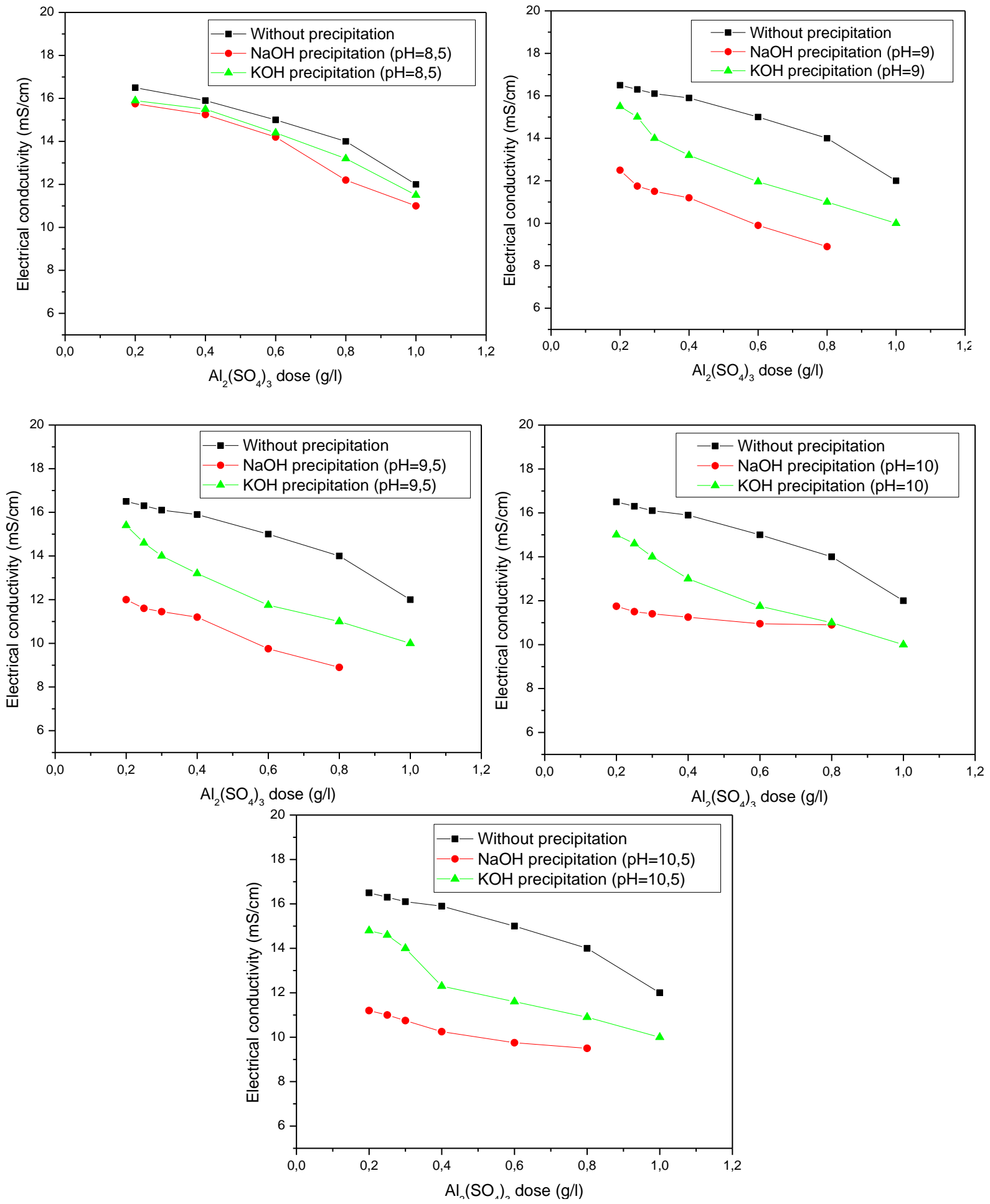
Fig.4 Orthophosphates concentration variation as function of coagulant dose
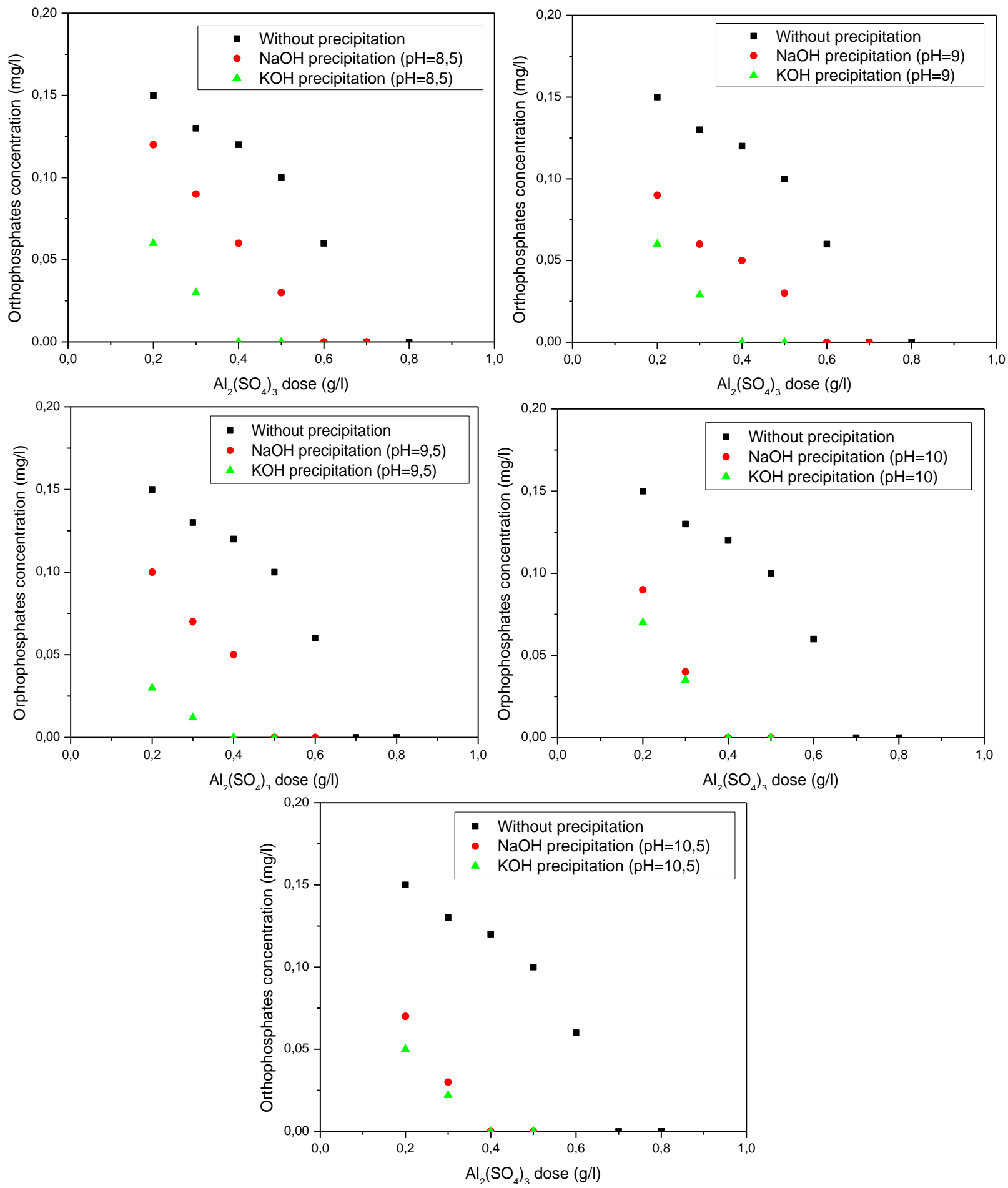
Fig.5 Oxidability variation as function of coagulant dose
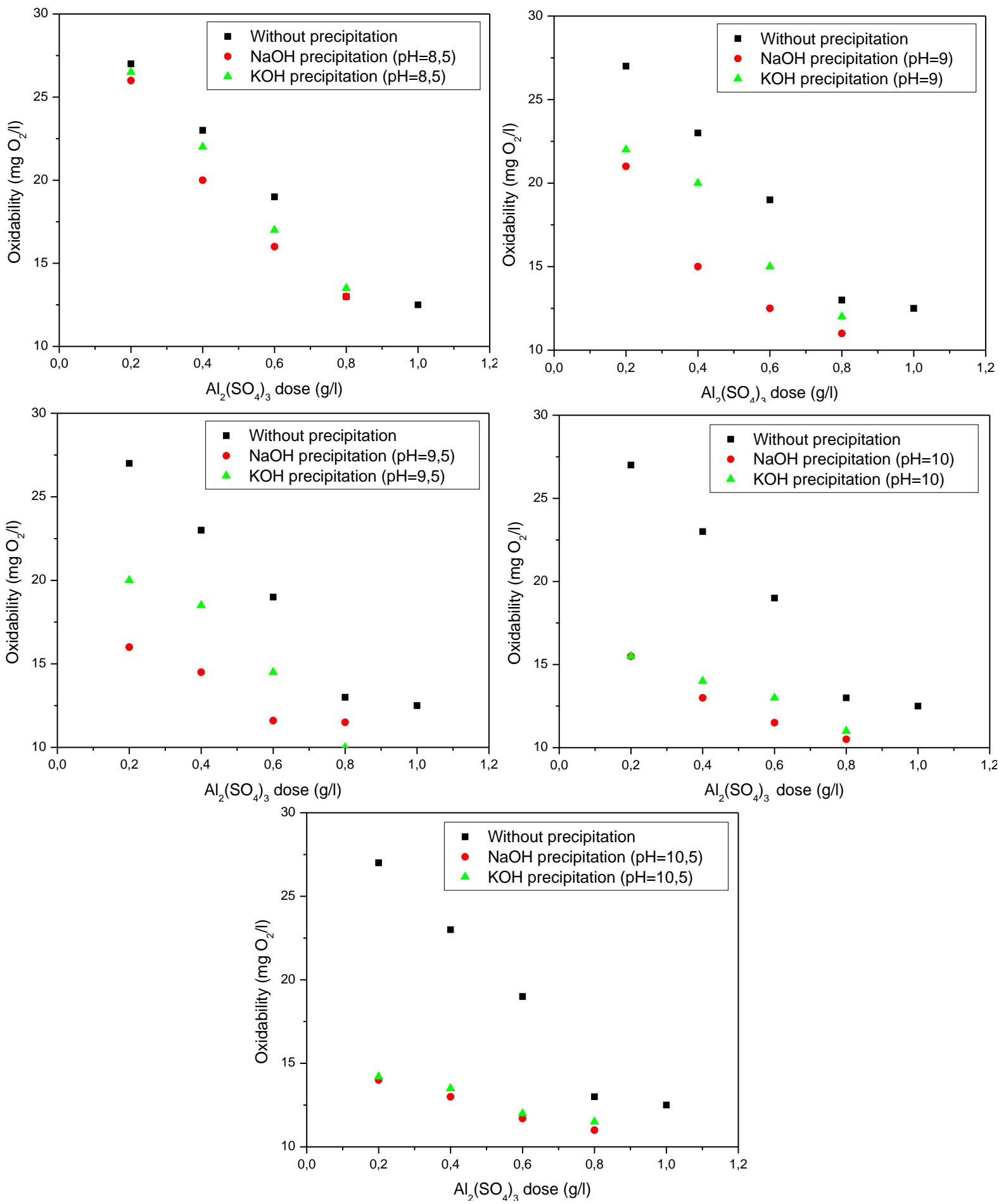
Fig.6 Turbidity variation as function of anionic flocculant for $\mathrm{NaOH}$ precipitation
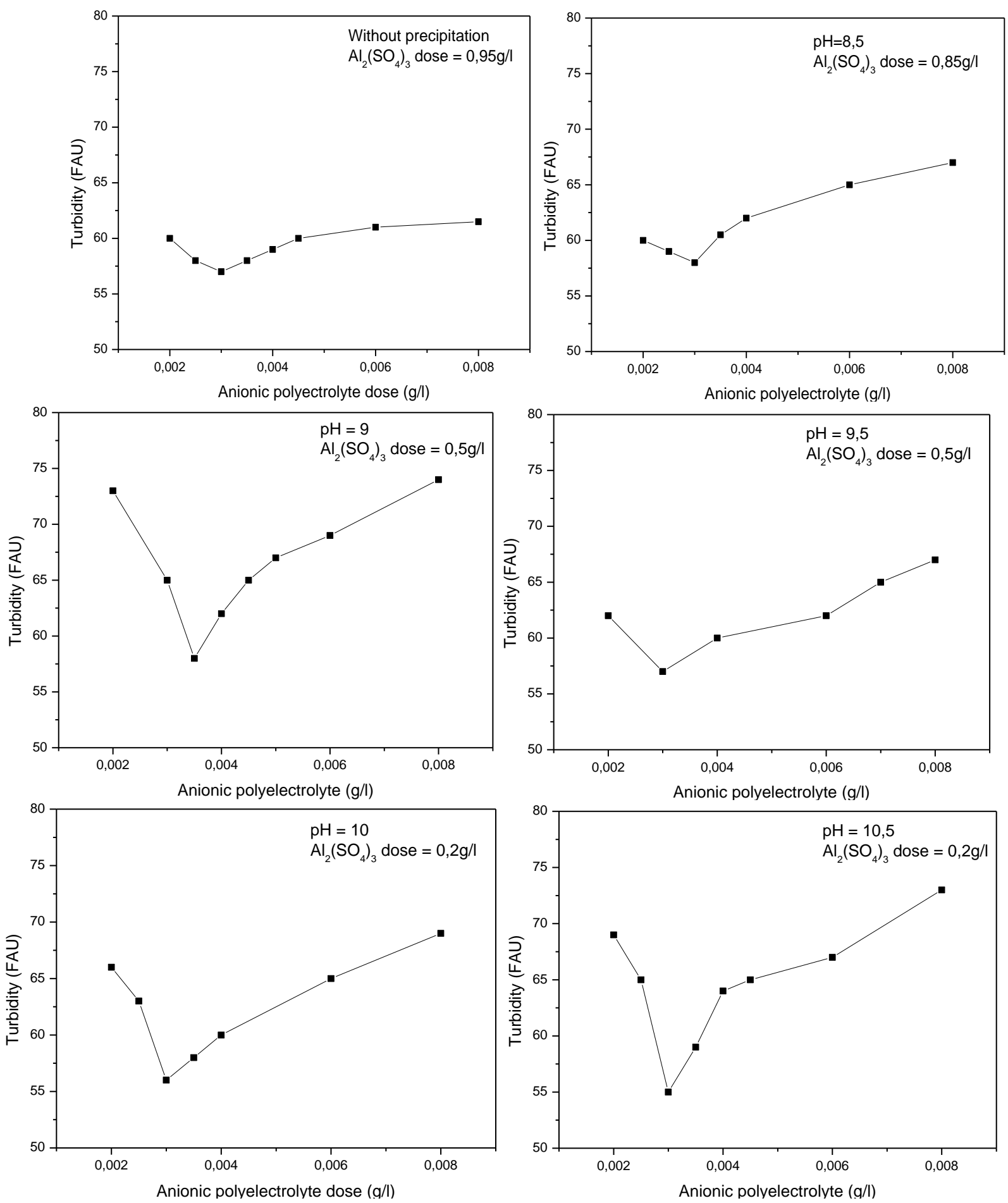
Fig.7 Characteristics of leachates treated by adsorption with activated carbon
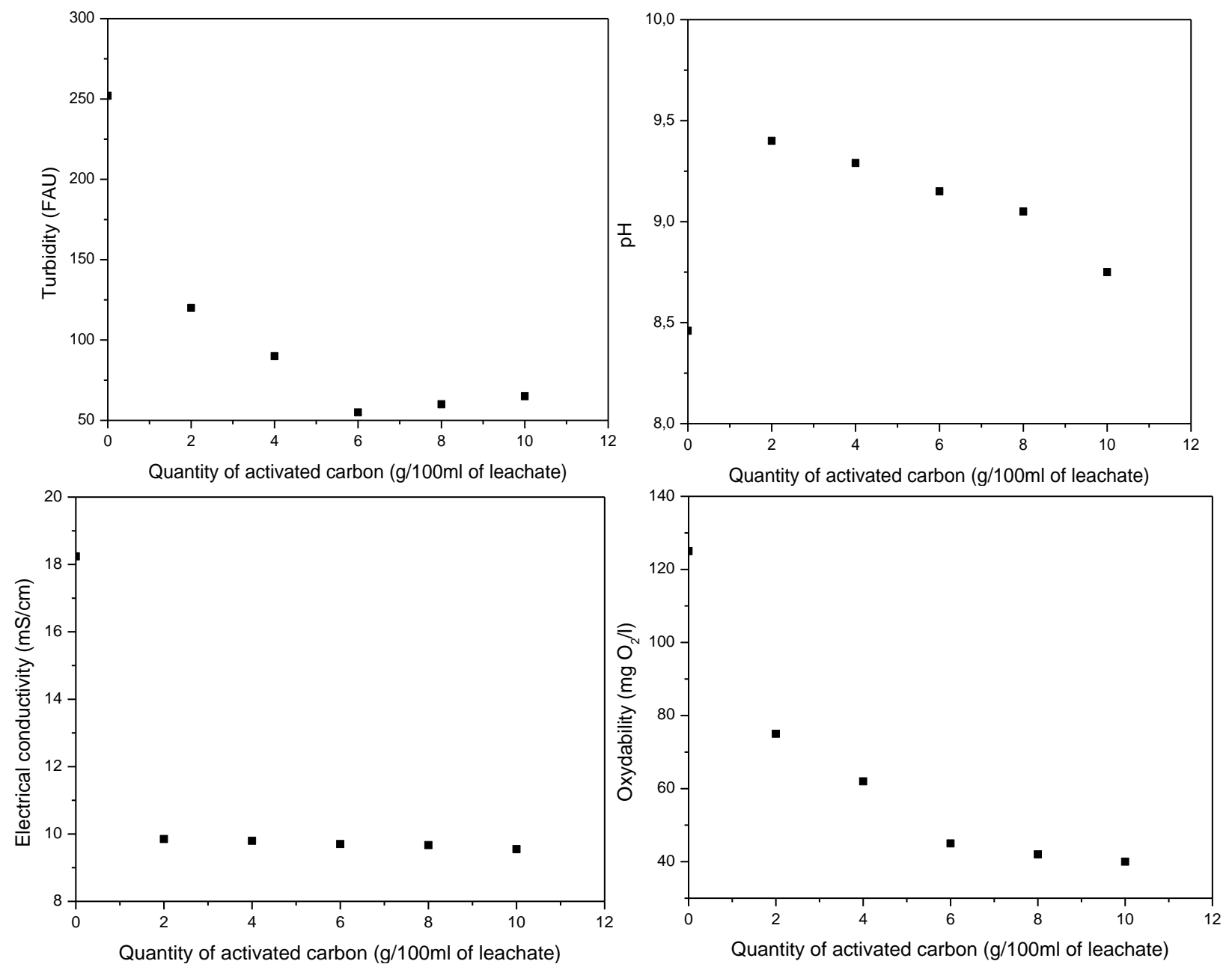

Table 6: Tracking parameters of treated leachate using adsorption

\begin{tabular}{|c|c|c|c|}
\hline Adsorbent type & Palm leaves & Alep pine bark & Activated carbon \\
\hline Adsorbent quantity $(\mathrm{g})$ & 4 & 2 & 6 \\
\hline Stirring time $(\mathrm{min})$ & 30 & 120 & 120 \\
\hline $\mathrm{pH}$ & 8,81 & 9,14 & 9,40 \\
\hline Conductivity $(\mathrm{mS} / \mathrm{cm})$ & 9,52 & 9,60 & 9,71 \\
\hline $\mathrm{PO}_{4}^{3-}$ concentration $(\mathrm{mg} / \mathrm{l})$ & 0,75 & 0,50 & 0 \\
\hline Oxidability $(\mathrm{mg} \mathrm{O} / \mathrm{l})$ & 82 & 67 & 45 \\
\hline Turbidity $(\mathrm{FAU})$ & 128 & 93 & 53 \\
\hline
\end{tabular}


Fig.8: Leachates characteristics during its treatment using adsorption
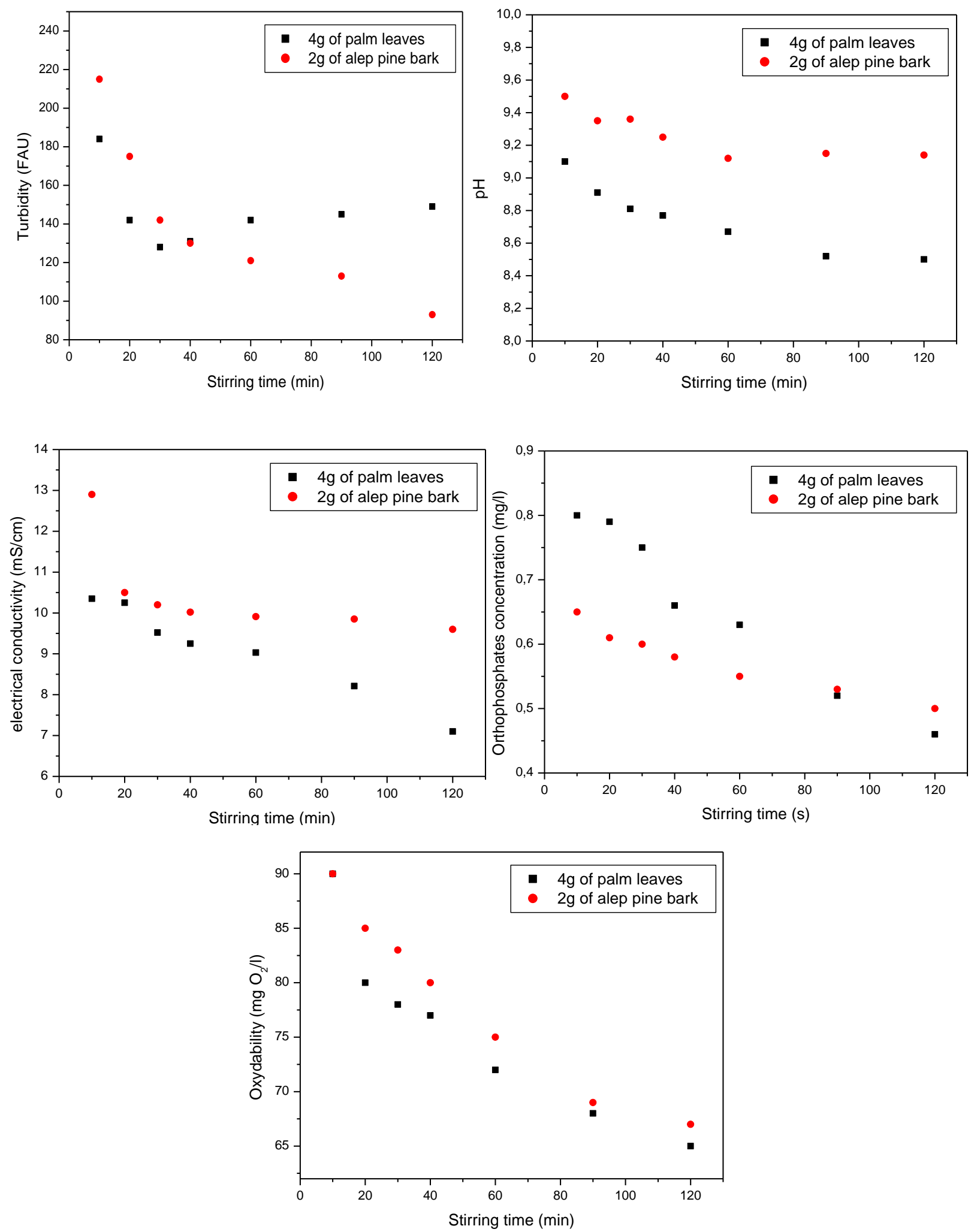
Despite the improvement in leachate quality, the dose of anionic polyelectrolyte remains at around $3 \mathrm{mg} / \mathrm{l}$ for precipitation at $\mathrm{pH}=8,5$ until a $\mathrm{pH}=10,5$. The same observations are made for precipitation with $\mathrm{KOH}$. After coagulation flocculation of leachate, the final solution has the characteristics presented in Table 4 and Table 5.

Concerning the effect of precipitation type on turbidity, sodium hydroxide and potassium hydroxide give similar results regardless of the $\mathrm{pH}$ of precipitation. Therefore, the choice between $\mathrm{NaOH}$ and $\mathrm{KOH}$ does not influence on turbidity.

After precipitation, and in order to have the lowest turbidity, the doses of coagulants and flocculants are on average lower for soda precipitation.

The difference in $\mathrm{pH}$, salinity, and oxidability of the final solution of leachate doesn't depend on the type of used base.

Precipitation eliminates orthophosphates, so no additional treatment is required to remove them.

In order to conclude, and in order to reduce the doses of $\mathrm{Al} 2$ (SO4)3 as a coagulant and the anionic polyelectrolyte as a flocculant, it is preferable to precipitate using soda than with potassium hydroxide.

\section{Leachate treatment by adsorption}

This part concerns the adsorption of the leachate by different adsorbents. The goal is to find the adsorbent to reduce the turbidity.

Several studies have been carried out on the treatment of leachate by adsorption on activated carbon. The adsorption of pollutants on activated carbon, in column (Lim et al., 2009) or in powder form (Agha et al., 2007) and (Li et al., 2010), gives a good rate of reduction of COD compared to chemical methods and whatever the initial concentration of Solution in organic matter. The active carbon adsorption method has been used with biological processes for the leachates treatment (Li et al., 2010; Bu et al., 2010). Rodriguez et al., (2004) studied the efficiency of different resins for the removal of bio-recalcitrant organic matter. The study showed that activated carbon had the highest adsorption capacity.

Their principal disadvantage consists of the need to regenerate the columns frequently and the high consumption of activated carbon as mentioned by Renou et al., (2008).

The activated carbon was initially used as an adsorbent. The variation of the leachate monitoring parameters as a function of the quantity of activated carbon per $100 \mathrm{ml}$ of leachate is shown in Fig.7.

It's observed that activated carbon has a good influence on each parameter. In contrast, Turbidity has a minimum of 53FAU for a quantity of activated carbon of $6 \mathrm{~g} / 100 \mathrm{ml}$ of leachate.

$\mathrm{pH}$, electrical conductivity, and oxidability decrease with the increase of adsorbent quantity. Several adsorbents have been used to determine which one will allow for minimum turbidity. Quantities from 2 to $10 \mathrm{~g}$ of each adsorbent are used. Several stirring times are tested. The raw leachate has an initial turbidity of 252FAU.

The selected adsorbents are $4 \mathrm{~g}$ of date palm leaves which give a turbidity of 140FAU and $2 \mathrm{~g}$ of Alep pine bark powder, the adsorption of which gives a turbidity of 93FAU. Activated carbon is used as a reference adsorbent. The variation of leachate characteristics for the two adsorbents is presented in Fig.8.

Choosing the date-palm leaves and pine bark Alep with specific quantities, the variation of the parameters of leachate are determined. The results are different from one parameter to another.

Note that the optimum of turbidity is for an adsorption using the pine bark of Alep after a stirring time of $120 \mathrm{~min}$. For this adsorbent, the 
turbidity decreases even after 120min of stirring. For the date palm leaves, the minimum turbidity is 128 for a stirring time of $30 \mathrm{~min}$.

For $\mathrm{pH}$ and electrical conductivity, these parameters decrease for both adsorbents. However, the use of date palm leaves has a considerable decrease compared to the other adsorbent. It's seen that the adsorbents used contain phosphorus. Then, it's better to use palm leaves which give a concentration of $0,45 \mathrm{mg} / 1$ after a stirring time of $120 \mathrm{~min}$ compared to $0,5 \mathrm{mg} / \mathrm{l}$ using the bark for the same stirring time.

Table 6 summarizes the tracking parameters leachate for minimum turbidity. It's observed that activated carbon is the best adsorbent for turbidity. After a stirring time of $120 \mathrm{~min}$, treated leachate has a turbidity of 53FAU. The Alep pine bark came in the second position with a turbidity of 93FAU for the same stirring time.

It is concluded that Leachates are a major problem for the environment due to their high pollutant content. The leachates selected have the following physicochemical characteristics: they have a turbidity of 252FAU, a $\mathrm{pH}$ of 8,46 and an electrical conductivity of $18,24 \mathrm{mS} / \mathrm{cm}$. The oxidability is about $125 \mathrm{mg}$ of $\mathrm{O} 2 / \mathrm{l}$ and the concentration of orthophosphate is about $0,35 \mathrm{mg} / \mathrm{l}$. Two types of treatment were considered: a chemical treatment by coagulation-flocculation and a biological treatment by adsorption. The coagulant used is Alumina sulfate and the flocculant is the anionic polyelectrolyte. A pretreatment is used before coagulation-flocculation. It's precipitation using caustic soda and the hydroxide of potassium. For the adsorbing agents, it is the date palm leaves and the bark of Alep pine in powders. Activated carbon is used as a reference adsorbent.

Leachates which were not pretreated have 57FAU of turbidity which corresponds to a $77 \%$ yield. The dose of alumina sulfate is about $0,95 \mathrm{~g} / \mathrm{l}$ and $3 \mathrm{mg} / \mathrm{l}$ of anionic polyelectrolyte. At this point, the $\mathrm{pH}$ is 6,64 ; the oxidability is
$11,5 \mathrm{mg} \mathrm{O} 2 / 1$ with the absence of phosphorus in this solution. This treated leachate is in discharge standard of Tunisia. However, it's necessary to pre-treat leachate in order to improve the quality of leachate and minimize coagulant doses of flocculants with lower costs.

Chemical precipitation with caustic soda at $\mathrm{pH}=10,5$ followed by coagulation-flocculation treatment decreases the dose of alumina sulfate to $0,2 \mathrm{~g} / \mathrm{l}$ for a turbidity efficiency of $78,17 \%$. However, this result requires a large quantity of soda $(255 \mathrm{ml} / \mathrm{l}$ of leachate) and this product and expensive compared with lime giving the same results with a small quantity $(0,2 \mathrm{~g} / \mathrm{l}$ of leachate). Then, using adsorption for leachate treatment requires the least investment cost. Adsorption with $2 \mathrm{~g}$ of Alep pine bark $/ 100 \mathrm{ml}$ of leachate gave the best results of turbidity. It gave a turbidity yield of $63 \%$, an oxidability of $67 \mathrm{mg}$ $\mathrm{O} 2 / 1$ and a phosphorus concentration of $0,5 \mathrm{mg} / \mathrm{l}$. This is why additional treatment is necessary.

\section{Acknowledgement}

This work was performed in the laboratory of chemistry and water quality of the higher engineering school of the rural equipment of Medjez El Bab (ESIER) in Tunisia. It was carried out as part of a master's degree.

\section{References}

Agha Mohammadi, N., Bin Abdul Aziz, H., Isa, M.A., Zinatizadeh, A.A. 2007. Powdered activated carbon augmented activated sludge process for treatment of semiaerobic landfill leachate using response surface methodology, Bioresource. Technol., 98: 3570-3578.

Amokrane, A., Comel, C., Veron, J. 1997. Landfill leachates pretreatment by coagulation flocculation, Water Res., 31: 2775-2782.

Baig, S., Coulomb, I., Courant, P., Liechti, P. 1999. Treatment of landfill leachates : Lapeyrouse and Starod case studies, Ozone Sci. Engi., Vol. 21, No. 1, pp 1-22.

Bu, L., Wang, K., Zhao, Q.L., Wei, L.L., Zhang, J., Yang, J.C. 2010. 
Characterization of dissolved organic matter during landfill leachate treatment by sequencing batch reactor, aeration corrosive cell-Fenton, and granular activated carbon in series, J. Hazard. Mater., 179: 1096-1105.

Edeline, F. 1993. L'épuration des lixiviats de décharge, Tribune de l'Eau, Vol. 46, No. 566, pp 57-65.

Ehrig, H.J. 1984. Treatment of sanitary landfill leachate: Biological treatment, Waste. Manage. Res., 2: 131-152.

Li, W., Hua, T., Zhou, Q., Zhang, S., Li, F. 2010. Treatment of stabilized landfill leachate by the combined process of coagulation/flocculation and powder activated carbon adsorption, Desalination, 264: 56-62.

Lim, Y.N., Ghazaly Shaaban, M., Yin, C.Y. 2009. Treatment of landfill leachate using palm shell activated carbon column: Axial dispersion modeling and treatment profile, J. Chem. Eng., 146: 86-89.

Papadopoulos, A., Fatta, D., Loizidou, M. 1998. Treatment of stabilised landfill leachate by physico-chemical and bio-oxidation processes, J. Environ. Sci. Health, Vol.33, No. 4, pp 651-670.

Renou, S., Givaudan, J.G., Poulain, S., Dirassouyan, F., Moulin, P. 2008. Landfill leachate treatment: Review and opportunity, J. Hazard. Mater., 150: 468493.
Rodriguez J., Castrillon L., Maranon E., Sastre H., Fernandez E., Removal of non biodegradable organic matter from landfill leachates by adsorption, Water Res. 38 (2004) 3297-3303.

Silva, A.C., Dezotti, M., Sant'Anna, Jr. G.L. 2004. Treatment and detoxication of a sanitary landfill leachate, Chemosphere, 55: 207-214.

Slater, C., Ahlert, R., Uchrin C. Treatment of landfilll leachates by Reserve osmosis. Environmental Progress, 2(4): pp: 251256.

Thornton, R., Blanc, F. 1973. Leachate treatment by coagulation and precipitation. J. Environ. Engi. Division, 8: pp : 535-544.

Trabelsi, S. 2012. Etudes de traitement des lixiviats des déchets urbains par les procédés d'oxydation avancée photochimiques et électrochimiques : application aux lixiviats de la décharge tunisienne "Jebel Chakir". Doctoral thesis submitted on 28 february 2012. 227pages.

Welanden, U., Henrysson, T. 1998. Physical and chemical treatment of nitrified leachate from a municipal landfill, Environ. Technol., Vol. 19, pp 591-599.

Zouboulis, A., Chai, X., Katsoyiannis, I. 2004. The application of bioflocculant for the removal of humic acids from stabilized landfill leachates, J. Environ. Manage., 70: $35-41$.

\section{How to cite this article:}

Zouaghi, H., and Ben Thayer, B. 2017. Treatment of Leachate from Urban Waste Using Coagulation-Flocculation and Adsorption. Int.J.Curr.Microbiol.App.Sci. 6(5): 1344-1362. doi: https://doi.org/10.20546/ijcmas.2017.605.146 